\title{
PENGARUH KUALITAS PRODUK TERHADAP KEPUASAN PELANGGAN DI RUMAH MAKAN “LESEHAN 88” MADIUN
}

\author{
Dian kristiana \\ Mahasiswa Prodi Pendidikan Ekonomi IKIP PGRI Madiun
}

\begin{abstract}
Abstrak.
This study aims to determine the quality of the product at home eating "Lesehan 88" Madiun, to determine customer satisfaction in restaurants "Lesehan 88" Madiun, and to know is there any effect of product quality on customer satisfaction in the eating "Lesehan 88" Madiun.

The samples in this study using a quota sample of 100 people, based on the characteristics of customers who have made a purchase at least once. Data collection using questionnaires and documentation. In analyzing the data used statistical method to test the product moment correlation is valid whether or not the instruments used and the method of regression tests for testing the hypothesis put forward in this study. The results showed that the quality of products have an influence a positive relationship to customer satisfaction in the eating "Lesehan 88" Madiun. It is derived from the value of 0.752 while the value rhitung rtabel $0.195(0.752 \geq 0.195)$. On the other hand Sighit value of 0.000 and the value Sigprob at 00:05 $(0.000 \leq 0.05)$ with the Ha acceptable means quality products have a relationship with customer satisfaction in restaurants "Lesehan 88" Madiun. It also obtained the $\mathrm{F}$ test value, while the value Fcount Ftable 3.938 $127.623(127.623 \geq 3.938)$. On the other hand Sigprob Sighit of 0.000 and 0.05 $(0.05 \leq 0.000)$. It means that there is rejection of $\mathrm{H} 0$ which indicates that there are significant between product quality to customer satisfaction in the eating "Lesehan 88" Madiun. Also obtained regression coefficients (t test) with tcount 11.297 1.660 while the value ttable $(\geq 11.2971 .660)$. On the other hand sighit value of 0.000 and Sigprob value of $0.05(0.05 \leq 0.000)$. By this means Ha received no difference between the effect of product quality on customer satisfaction in the restaurant "Lesehan 88" Madiun. R2 of 0,566, results showed that 56.6\% of customer satisfaction variables quality of the product, while the remaining $43.4 \%$ is influenced by other factors not examined.
\end{abstract}

Keyword: quality of products, customer satisfaction

\section{Pendahuluan}

Keberhasilan suatu usaha khususnya usaha rumah makan yang bergerak dibidang kuliner ditentukan oleh kualitas produk yang dihasilkan. Dengan kualitas produk yang baik untuk menarik pelanggan datang membeli produk yang dihasilkan dengan harapan pelanggan akan puas terhadap barang atau jasa yang dikonsumsi.

Produk yang ada di setiap rumah makan berbeda-beda, mempunyai ciri khas masing-masing misalnya, menyediakan masakan khas jawa, masakan padang, masakan pedas, chinese food, dan lain sebagainya. Produk makanan dan 
minuman yang ada di rumah makan sangatlah bersifat subyektif dimata pelanggan. Antara pelanggan 1 dengan yang lain berbeda dalam memberikan penilaian. Banyak hal yang dipertimbangkan oleh pelanggan sebelum membeli produk, misalnya harga produk, lokasi rumah makan, dan menu makanan. Selain itu pelanggan juga akan mempertimbangkan kualitas produk yang disediakan oleh rumah makan. Jadi rumah makan yang bijak akan menjual manfaat produk sekaligus memperhatikan kualitas produk untuk memenuhi kebutuhan dan keinginan pelanggan.

Menurut M.N Nasution, (2001: 45\&46) "Kepuasan pelanggan merupakan suatu keadaan dimana kebutuhan, keinginan, dan harapan pelanggan dapat terpenuhi melalui produk yang dikonsumsi. Jika pelanggan merasakan kualitas produk melebihi kebutuhan, keinginan dan harapan, maka kepuasan pelanggan akan menjadi tinggi. Disisi lain, apabila pelanggan merasakan bahwa kualitas produk lebih rendah atau lebih kecil dari kebutuhan, keinginan, dan harapan, maka kepuasan pelanggan akan menjadi rendah". Kepuasan pelanggan merupakan faktor yang penting bagi kelangsungan hidup usaha untuk bertahan dalam persaingan yang semakin ketat. Dengan cara mempertahankan pelanggan berarti mengharapkan pelanggan melakukan pembelian kembali atas produk dan jasa. Setiap usaha harus memberikan kepuasan kepada pelanggan dengan cara memperhatikan apa yang dibutuhkan oleh pelanggan, salah satunya kualitas produk yang dihasilkan.

Kualitas produk merupakan salah satu tolok ukur yang digunakan dalam upaya memingkatkan kepuasan pelanggan. Kualitas produk dalam usaha rumah makan dapat dilihat dari kebersihan produk, cita rasa, menu, dan porsi makanan. Oleh karena itu untuk mempertahankan pelanggan maka harus menjaga konsistensi kualitas produk yang dihasilkan, dan pada akhirnya kepuasan pelanggan dapat terpenuhi.

Kepuasan pelanggan merupakan faktor yang penting bagi kelangsungan hidup usaha untuk bertahan dalam persaingan yang semakin ketat. Dengan cara mempertahankan pelanggan berarti mengharapkan pelanggan melakukan pembelian kembali atas produk dan jasa. Setiap usaha harus memberikan kepuasan kepada pelanggan dengan cara memperhatikan apa yang dibutuhkan oleh pelanggan. Sampai saat ini masih banyak usaha rumah makan yang belum bisa memberikan kepuasan pelanggan, karena kurang memperhatikan kualitas produk yang dihasilkan.

Menurut Garvin (dalam M.N Nasution, 2001: 16) mengatakan "kualitas adalah suatu kondisi dinamis yang berhubungan dengan produk, manusia/tenaga kerja, proses dan tugas, serta lingkungan yang memenuhi atau melebihi harapan pelanggan atau konsumen". Selera atau harapan konsumen pada suatu produk selalu berubah sehingga kualitas produk juga harus berubah atau disesuaikan. Dengan perubahan kualitas produk tersebut, diperlukan perubahan atau peningkatan kualitas agar produk dapat memenuhi atau melebihi harapan pelanggan.

Sementara itu American Society for Quality Control (dalam Thamrin Abdullah dan Franciss Tantri, 2012: 44) "kualitas adalah keseluruhan ciri dan 
karakteristik suatu barang atau jasa yang berpengaruh pada kemampuannya untuk memuaskan kebutuhan yang dinyatakan maupun yang tersirat".

Sedangkan menurut Juran (dalam M.N Nasution, 2001: 15), Kualitas produk adalah kecocokan penggunaan produk (fitness for use) untuk memenuhi kebutuhan dan kepuasan pelanggan. Ciri atau karakteristik produk disini harus memenuhi tuntutan pelanggan dan tidak memiliki kelemahan. Dari kualitas produk itulah kepuasan pelanggan dapat dicapai.

Jadi kualitas adalah keseluruhan ciri dan karakteristi produk barang atau jasa dalam tujuannya untuk memenuhi kebutuhan dan harapan pelanggan. Sedangkan kualitas produk adalah kemampuan ciri dan karakteristik produk barang atau jasa dalam usahanya untuk mencapai kebutuhan pelanggan. Kualitas sebagai ukuran dalam pencapaian usaha, dimana jika pelaku bisnis khususnya usaha rumah makan dalam era globalisasi sekarang ini jika tidak berfokus pada kualitas akan kalah dalam persaingan.

Kepuasan pelanggan merupakan indikator kesuksesan bisnis dimasa depan yang mengukur kecenderungan reaksi pelanggan terhadap usaha dimasa datang (Fandy Tjiptono. 2005: 354). Untuk itu setiap usaha harus bisa memberikan kepuasan kepada pelanggan, baik dari segi produk maupun kualitas pelayanan agar tidak ditinggalkan oleh pelanggan. Setiap usaha khususnya rumah makan harus dapat menciptakan dan mempertahankan pelanggan. Mempertahankan pelanggan berarti mengharapkan pelanggan melakukan pembelian kembali atas produk dan jasa pada saat kebutuhan yang sama muncul dikemudian hari. Untuk menciptakan pembelian kembali maka perusahaan harus memberikan kepuasan kepada pelanggan.

Dilain pihak Kotler, (dalam Fandy Tjiptono dan Anastasia Diana, 2002: 102) mengatakan "kepuasan pelanggan adalah tingkat perasaan seseorang setelah membandingkan kinerja (atau hasil) yang ia rasakan dibandingkan dengan harapannya".

Sementara itu M.N Nasution, (2001: 60) menyatakan "kepuasan pelanggan merupakan suatu keadaan dimana kebutuhan, keinginan, dan harapan pelanggan dapat terpenuhi pada suatu produk yang dikonsumsi".

Sedangkan Zulian Yamit, (2005: 78) mengatakan kepuasan pelanggan adalah hasil (outcome) yang dirasakan atas penggunaan produk dan jasa, sama atau melebih harapan yang diinginkan.

Jadi kepuasan pelanggan merupakan suatu perasaan atau penilaian emosional dari pelanggan atas penggunaan suatu produk barang atau jasa dimana kebutuhan, keinginan, dan harapan pelanggan dapat terpenuhi pada suatu produk yang dikonsumsi

Dalam mewujudkan kepuasan pelanggan yang telah dikemukakan terdahulu dibutuhkan waktu dan usaha dari masing-masing pelaku bisnis. Untuk mempertahankan pelanggan dibutuhkan konsistensi kualitas produk yang dihasilkan, misalnya tingkat kebersihan, menu yang bervariasi, cita rasa yang sesuai, dan porsi yang pas. Sehingga kebutuhan dan keinginan dan kebutuhan pelanggan dapat tercapai.

Pada dasarnya kualitas produk berpengaruh dalam upaya mewujudkan kepuasan pelanggan. Produk yang berkualitas tinggi akan dipilih pelanggan 
karena kualitas mengacu kepada segala sesuatu yang menentukan kepuasan pelanggan, suatu produk yang dihasilkan baru dapat dikatakan berkualitas apabila sesuai dengan keinginan pelanggan, dapat memberikan kepuasan, serta diolah dengan cara yang baik dan benar. Hal ini harus diperhatikan secara cermat sebab dapat mempengaruhi sikap pelanggan terhadap produk, sikap pelanggan ini sangat bervariasi tergantung dari orientasinya maka pihak rumah makan dapat mengidentifikasi segmen pelanggan berdasarkan kualitas produk yang diinginkan oleh pelanggan.

Kualitas produk merupakan kemampuan dari suatu produk dalam menjalankan fungsinya. Kualitas produk mempunyai hubungan yang sangat erat dengan kepuasan pelanggan karena kualitas produk dapat dinilai dari kemampuan produk tersebut untuk menciptakan kepuasan pelanggan. Untuk memuaskan pelanggan maka, rumah makan di dalam pengolahan produk harus berkualitas dan menjaga konsistensi kualitas produk yang dihasilkan. Meskipun pelanggan memiliki persepsi yang berbeda terhadap kualitas produk, tetapi setidaknya pelanggan akan memilih produk dengan kualitas yang mampu memuaskan kebutuhannya. Kualitas produk merupakan faktor dasar yang mempengaruhi kepuasan pelanggan.

\section{DIMENSI KUALITAS PRODUK}

Dimensi kualitas merupakan syarat agar suatu nilai dari produk memungkinkan untuk bisa memuaskan pelanggan sesuai harapan. Menurut Joseph S. Martinich (dalam Zulian Yamit, 2005: 11) mengatakan terdapat enam spesifikasi dimensi kualitas produk yang relevan dengan pelanggan yaitu:

1. Performance, yaitu kualitas produk menggambarkan keadaan yang sebenarnya atau apakah pelayanan diberikan dengan cara yang benar.

2. Range and type of features, yaitu pelanggan sering kali tertarik pada kemampuan atau keistimewaan yang dimiliki produk dan pelayanan.

3. Reliability dan Durability, yaitu kehandalan produk dalam penggunaan secara normal dan berapa lama produk dapat digunakan hingga perbaikan diperlukan.

4. Maintainability and serviceability, yaitu kemudahan untuk mengoperasikan produk dan kemudahan perbaikan maupun ketersediaan komponen pengganti.

5. Sensory characteristics, yaitu penampilan, corak, rasa, daya tarik, bau, selera yang mungkin menjadi aspek penting dalam kualitas produk.

6. Ethical Profile and Image, kualitas adalah bagian terbesar dari pelanggan terhadap produk dan pelayanan.

Sedangkan Garvin, (dalam M.N Nasution, 2001: 17-18) mendefinisikan delapan dimensi yang dapat digunakan untuk menganalisis karakteristik kualitas produk, yaitu:

1. Performa (performance) berkaitan dengan aspek fungsional dari produk dan merupakan karakteristik utama yang dipertimbangkan pelanggan ketika ingin membeli suatu produk.

2. Features merupakan aspek kedua dari performa yang menambah fungsi dasar, berkaitan dengan pilihan-pilihan dan pengembangannya. 
3. Keandalan (reliability) berkaitan dengan kemungkinan suatu produk berfungsi secara berhasil dalam periode waktu tertentu di bawah kondisi tertentu.

4. Konformitas (conformance) berkaitan dengan tingkat kesesuaian produk terhadap spesifikasi yang telah ditetapkan sebelumnya berdasarkan keinginan pelanggan.

5. Daya tahan (durability) merupakan ukuran masa pakai suatu produk.Karakteristik ini berkaitan dengan daya tahan suatu produk

6. Kemampuan pelayanan (service ability) merupakan karakteristik yang berkaitan dengan kecepatan/kesopanan, kompetensi, kemudahan, serta akurasi dalam perbaikan.

7. Estetika (aesthetics) merupakan karakteristik mengenai keindahan yang bersifat subyektif sehingga berkaitan dengan pertimbangan pribadi dan refleksi dari preferensi atau pilihan individual.

8. Kualitas yang dipersepsikan (perceived quality) bersifat subyektif, berkaitan dengan perasaan pelanggan dalam mengkonsumsi produk, seperti meningkatkan harga diri.

\section{FAKTOR-FAKTOR YANG MEMPENGARUHI KEPUASAN PELANGGAN}

Setiap usaha rumah makan selalu berkeinginan agar produk yang dimiliki mampu memberikan kepuasan pelanggan yang maksimal. Ada beberapa faktor yang mempengaruhi kepuasan pelanggan.

Menurut Rambat Lupiyoadi (2001: 158) menyatakan ada lima faktor utama yang perlu diperhatikan dalam kaitannya dengan kepuasan pelanggan diantaranya:

1. Kualitas produk

Pelanggan akan puas bila hasil evaluasi mereka menunjukkan bahwa produk yang mereka gunakan berkualitas, yakni sesuai dengan harapan dan keinginan pelanggan.

2. Kualitas pelayanan

Pelanggan akan merasa puas bila mendapatkan pelayanan yang baik atau yang sesuai dengan harapan.

3. Emosional

Pelanggan akan merasa bangga dan mendapatkan keyakinan bahwa orang lain akan kagum bila seseorang menggunakan produk yang berkualitas dan cenderung mempunyai kepuasan yang lebih tinggi.

4. Harga

Produk yang mempunyai kualitas yang sama tetapi menetapkan harga relatif murah akan memberikan nilai yang lebih tinggi pada pelanggannya.

5. Biaya

Pelanggan yang tidak perlu mengeluarkan biaya tambahan atau tidak perlu membuang waktu untuk mendapatkan produk atau jasa cenderung puas terhadap produk atau jasa tersebut. 


\section{PENGUKURAN KEPUASAN PELANGGAN}

Di atas sudah disimpulkan bahwa kepuasan pelanggan adalah suatu perasaan atau penilaian emosional dari pelanggan atas penggunaan suatu produk barang atau jasa dimana kebutuhan, keinginan, dan harapan pelanggan dapat terpenuhi pada suatu produk yang dikonsumsi. Oleh karena itu perlunya pengukuran kepuasan pelanggan untuk mengetahui produk yang dirasakan pelanggan melebihi atau kurang dari harapan yang diinginkan pelanggan. Di bawah ini ada beberapa pendapat untuk mengukur kepuasan pelanggan.

M.N Nasution, (2001: 55) mengatakan ada empat metode dalam pengukuran kepuasan pelanggan sebagaimana dikemukakan berikut ini:

a) Sistem keluhan dan saran

Sistem ini memberikan fasilitas kepada pelanggan untuk memberikan kritikan maupun saran kepada pemilik usaha. Misalnya dengan menyediakan kotak saran, kartu komentar, dan lain-lain. Informasi ini memberikan ideide/gagasan untuk memperbaiki kualitas produk yang dapat memuaskan pelanggan.

b) Ghost shopping

Cara untuk memperoleh gambaran mengenai kepuasan pelanggan adalah dengan mempekerjakan beberapa orang (Ghost Shopper) untuk berperan atau bersikap sebagai pelanggan pembeli potensial produk usaha dan pesaing. Kemudian mereka melaporkan temuannya mengenai kekuatan dan kelemahan produk usaha dan pesaing berdasarkan pengalaman mereka dalam pembelian produk-produk tersebut

c) Lost customer analysis

Setiap usaha seyogyanya menghubungi para pelanggan yang telah berhenti membeli atau pindah pemasok agar dapat memahami mengapa hal ini terjadi dan supaya dapat mengambil kebijakan perbaikan / penyempurnaan selanjutnya.

d) Survei kepuasan pelanggan

Metode ini untuk mengetahui kepuasan pelanggan dengan melakukan survey, baik melalui kuesioner, telepon, maupun wawancara pribadi melalui survey akan memperoleh tanggapan dan umpan balik secara langsung dari konsumen dan juga memberikan tanda positif bahwa usaha rumah makan menaruh perhatian terhadap para pelanggannya.

\section{METODE PENELITIAN}

Tempat penelitian dilaksanakan di rumah makan "Lesehan 88", Jalan Diponegoro No. 39 Madiun. Rancangan penelitian yang digunakan dalam penelitian ini adalah penelitian deskriptif kuantitatif. Penelitian deskriptif ini bertujuan untuk menggambarkan/memecahkan masalah secara sistematis, faktual, dan akurat mengenai fakta-fakta dan sifat-sifat populasi atau daerah tertentu, (Usman Rianse dan Abdi, 2012: 30). Sedangkan metode kuantitatif adalah metode penelitian yang berlandaskan pada filsafat positivisme, digunakan untuk meneliti pada populasi atau sampel tertentu, pengumpulan data menggunakan instrumen penelitian, analisis data bersifat kuantitatif/statistik, dengan tujuan untuk menguji hipotesis yang telah ditetapkan, (Sugiyono, 2007: 8). 
Rancangan penelitian dapat dilihat pada gambar sebagai berikut.

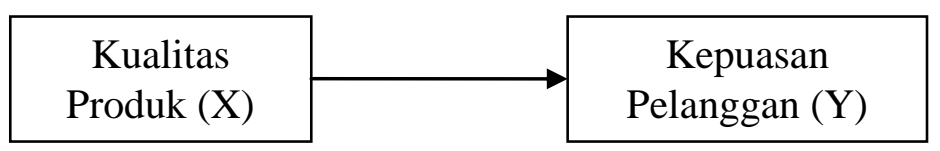

\section{Variabel Penelitian}

\section{Gambar Desain Penelitian}

Dalam penelitian ini yang menjadi variabel bebas $(\mathrm{X})$ adalah kualitas produk dan variabel terikat (Y) adalah kepuasan pelanggan.

Adapun definisi operasional variabel-variabel tersebut adalah sebagai berikut:

1. Kualitas produk adalah kecocokan penggunaan produk (fitness for use) untuk memenuhi kebutuhan dan kepuasan pelanggan, Juran (dalam M.N Nasution, 2001: 15). Indikator untuk kualitas produk adalah produknya higienis, cita rasa sesuai harapan, menu yang bervariasi, dan porsi yang pas.

2. Kepuasan pelanggan adalah hasil (outcome) yang dirasakan atas penggunaan produk dan jasa, sama atau melebih harapan yang diinginkan (Zulian Yamit, 2005: 78). Indikator untuk kepuasan pelanggan adalah kualitas bahan/produk, kualitas sajian, sesuai harapan/persepsi pelanggan, dan harga.

\section{Teknik Pengumpulan Data}

Teknik pengumpulan data yang digunakan peneliti dalam melakukan penelitian adalah:

1. Kuesioner

Jumlah soal dalam angket ini adalah 24 soal yang terbagi dalam 2 variabel yang akan diteliti. 12 soal untuk variabel kualitas produk (X) dan 12 soal yang lain variabel kepuasan pelanggan (Y).

Instrumen yang digunakan dalam penelitian ini adalah berupa kuesioner. Sistem yang digunakan adalah berupa pemberian skor berdasarkan Skala Likert. Sugiyono (2006: 93) menyatakan bahwa skala likert adalah skala yang digunakan untuk mengukur sikap, pendapat, dan persepsi seseorang atau sekelompok orang tentang fenomena sosial.

2. Dokumentasi

Metode ini dipergunakan untuk memperoleh data yang menunjang data penelitian, seperti profil rumah makan, daftar menu makanan, dan harga menu makanan.

\section{Populasi dan sampel Penelitian}

Populasi dalam penelitian ini adalah adalah pelanggan yang telah membeli produk makanan dan minuman di rumah makan "Lesehan 88 " Madiun, dengan jumlah tak terhingga. Berdasarkan jumlah populasi tersebut maka sampel dalam penelitian ini adalah pelanggan rumah makan "Lesehan 88" Madiun sebanyak 100 pelanggan.

Teknik yang digunakan dalam pengambilan sampel untuk penelitian ini adalah teknik sampel kuota (sampling kuota) adalah teknik penentuan sampel dari populasi yang mempunyai ciri-ciri tertentu sampai jumlah (kuota) yang 
diinginkan. Ciri yang digunakan adalah responden yang telah melakukan pembelian di rumah makan "Lesehan 88 " minimal 1 kali.

\section{HASIL PENELITIAN \\ Variabel Kualitas Produk}

Deskripsi dari variabel kualitas produk dengan jumlah data $(\mathrm{N})$ sebanyak 100 mempunyai deskripsi data sebagai berikut: (a) Jumlah skor total sebesar 4779; (b) Mean sebesar 47.79; (c) Median sebesar 48,00; (d) Modus sebesar 48; (e) standar deviasi sebesar 5,392; (f) Variance sebesar 29,077; (g) Range sebesar 27; (h) Nilai minimum sebesar 33; (i) Nilai maximum sebesar 60.

Dari hasil analisis statistik deskriptif kualitas produk di atas dapat diketahui responden dari kuesioner yang telah disebarkan yang berada di atas nilai rata-rata sebanyak 74 pelanggan atau $74 \%$. Sedangkan sisanya 26 pelanggan atau $26 \%$ berada di bawah nilai rata-rata. Hal ini dapat disimpulkan kualitas produk di rumah makan "Lesehan 88 " Madiun adalah baik.

\section{Variabel Kepusan Pelanggan}

Deskripsi dari variabel kepuasan pelanggan dengan jumlah data $(\mathrm{N})$ sebanyak 100 mempunyai deskripsi data sebagai berikut: (a) Jumlah skor total sebesar 4884; (b) Mean sebesar 48.84; (c) Median sebesar 48,00; (d) Mode sebesar 48; (e) Standar deviasi sebesar 5,541; (f) Variance sebesar 30,701; (g) Range sebesar 27; (h) Nilai minimum sebesar 33; (i) Nilai maximum sebesar 60.

Dari hasil analisis statistik deskriptif kepuasan pelanggan di atas dapat diketahui responden dari kuesioner yang telah disebarkan yang berada di atas nilai rata-rata sebanyak 72 pelanggan atau $72 \%$. Sedangkan sisanya 28 pelanggan atau $28 \%$ berada di bawah nilai rata-rata. Hal ini dapat disimpulkan kualitas produk di rumah makan "Lesehan 88 " madiun adalah baik.

\section{Hasil Uji Korelasi}

Hasil uji korelasi didapat besarnya nilai $r_{\text {hitung }}$ sebesar 0,752 sedangkan $r_{\text {tabel }}$ dengan $n=100$ dan probabilitas 0,05 sebesar 0,195. Dilain pihak nilai Sighit sebesar 0,000 dan Sig prob sebesar 0,05. Hal ini berarti nilai $r_{\text {hitung }} \geq r_{\text {tabel }}(0,752 \geq$ $0,195)$ atau $\operatorname{Sig}_{\text {hit }} \leq \operatorname{Sig}_{\text {prob }}(0,000 \leq 0,05)$. Atas dasar uji korelasi tersebut dapat disimpulkan bahwa $\mathrm{H}_{0}$ ditolak, artinya ada hubungan antara kualitas produk dengan kepuasan pelanggan di rumah makan "Lesehan 88" Madiun. Dilain pihak dalam uji determinasi diperoleh nilai $\mathrm{R}^{2}$ ( $\mathrm{R}$ Square) atau koefisien determinasi yang digunakan untuk mengetahui seberapa besar prosentase sumbangan kualitas produk terhadap kepuasan pelanggan. nilai $\mathrm{R}^{2}$ adalah 0,566. Jadi sumbangan pengaruh dari kualitas produk terhadap kepuasan pelanggan yaitu 56,6\% sedangkan sisanya 43,4\% dipengaruhi oleh faktor lain yang tidak diteliti.

\section{Hasil Uji Fisher}

Dari hasil uji Fisher diperoleh besarnya nilai $F_{\text {hitung }}$ sebesar 127,623 sedangkan nilai $\mathrm{F}_{\text {tabel }}$ dengan $\mathrm{n}=100$ dan probabilitas 0,05 sebesar 3,938. Dilain pihak nilai $\mathrm{Sig}_{\text {hit }}$ sebesar 0,000 dan $\mathrm{Sig}_{\text {prob }}$ sebesar 0,05. Hal ini berarti bahwa nilai $F_{\text {hitung }} \geq F_{\text {tabel }}(127,623 \geq 3,938)$ dan $\operatorname{Sig}$ hit $\leq \operatorname{Sig}_{\text {prob }}(0,000 \leq 0,05)$. Atas dasar hasil uji Fisher tersebut dapat disimpulkan bahwa $\mathrm{H}_{0}$ ditolak, artinya ada 
pengaruh antara kualitas produk terhadap kepuasan pelanggan di rumah makan "Lesehan 88" Madiun.

Selain untuk mencari pengaruh uji $\mathrm{F}$ atau Anova ini bisa juga digunakan untuk menguji linearitas. Karena $F_{\text {hitung }}$ sebesar 127,623 $\geq F_{\text {tabel }}$ sebesar 3,938. Berarti ada hubungan yang linear antar dua variabel kualitas produk dengan kepuasan pelanggan.

\section{Hasil Uji t}

\begin{tabular}{|c|c|c|c|c|c|c|}
\hline \multicolumn{7}{|c|}{ Coefficients $^{\mathrm{a}}$} \\
\hline & \multirow{2}{*}{ Model } & \multicolumn{2}{|c|}{$\begin{array}{l}\text { Unstandardized } \\
\text { Coefficients }\end{array}$} & \multirow{2}{*}{$\begin{array}{c}\text { Standardized } \\
\text { Coefficients } \\
\text { Beta }\end{array}$} & \multirow[t]{2}{*}{$\mathrm{t}$} & \multirow[t]{2}{*}{ Sig. } \\
\hline & & $\mathrm{B}$ & Std. Error & & & \\
\hline \multirow{2}{*}{1} & (Constant) & 11.907 & 3.290 & & 3.619 & .000 \\
\hline & Kualitas_produk & .773 & .068 & .752 & 11.297 & .000 \\
\hline & 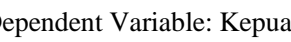 & 1. & & & & \\
\hline
\end{tabular}

Atas dasar tabel di atas dapat dibuat persamaan garis regresi sebagai berikut: $\mathrm{Y}=11,907+0,773 \mathrm{X}$. artinya apabila kualitas produk meningkat sebanyak $1 \%$ kepuasan pelanggan akan meningkat pula sebesar $0,773 \%$, apabila faktor lainnya tetap. Dari hasil perhitungan diperoleh nilai $t_{\text {hitung }}$ sebesar 11,297 sedangkan $t_{\text {tabel }}$ sebesar 1,660. Dilain pihak nilai $\mathrm{Sig}_{\text {hit }}$ sebesar 0,000 sedangkan $\operatorname{Sig}_{\text {prob }} 0,05$. Hal ini berarti nilai $t_{\text {hitung }} \leq t_{\text {tabel }}(11,297 \geq 1,660)$ atau $\operatorname{Sig}_{\text {hit }} \leq \operatorname{Sig}_{\text {prob }}$ $(0,000 \leq 0,05)$. Atas dasar uji t tersebut dapat disimpulkan bahwa $\mathrm{H}_{\mathrm{a}}$ diterima, artinya ada beda pengaruh antara kualitas produk terhadap kepuasan pelanggan di rumah makan "Lesehan 88" Madiun.

\section{Simpulan Hasil Analisis} berikut.

Atas dasar hasil pengujian hipotesis dapat diambil simpulan sebagai

\section{Simpulan Uji Korelasi}

Hasil dari pengujian korelasi dapat diperoleh besarnya nilai $r_{\text {hitung }}$ sebesar 0,752 sedangkan $r_{\text {tabel }}$ dengan $n=100$ dan probabilitas 0,05 sebesar 0,195 . Dilain pihak nilai $\mathrm{Sig}_{\text {hit }}$ sebesar 0,000 dan Sig $\mathrm{g}_{\text {prob }}$ sebesar 0,05. Hal ini berarti nilai $r_{\text {hitung }}$ $\geq r_{\text {tabel }}(0,752 \geq 0,195)$ atau $\operatorname{Sig}_{\text {hit }} \leq \operatorname{Sig}_{\text {prob }}(0,000 \leq 0,05)$. Selain itu diperoleh nilai $\mathrm{R}^{2}$ adalah 0,566 . Jadi sumbangan pengaruh dari kualitas produk terhadap kepuasan pelanggan yaitu $56,6 \%$.

Sesuai hipotesis yang diajukan dapat diperoleh simpulan bahwa ada hubungan kualitas produk dengan kepuasan pelanggan di rumah makan "Lesehan 88" Madiun. Berarti $\mathrm{H}_{0}$ ditolak, dan $\mathrm{H}_{\mathrm{a}}$ diterima.

\section{Simpulan Uji Fisher}

Simpulan dari pengujian fisher dengan uji Anova dapat diperoleh nilai $\mathrm{F}_{\text {hitung }}$ sebesar 127,623 sedangkan nilai $\mathrm{F}_{\text {tabel }}$ dengan $\mathrm{n}=100$ dan probabilitas 0,05 sebesar 3,938. Dilain pihak nilai $\mathrm{Sig}_{\text {hit }}$ sebesar 0,000 dan $\mathrm{Sig}_{\text {prob }}$ sebesar 0,05. Hal ini berarti bahwa nilai $F_{\text {hitung }} \geq F_{\text {tabel }}(127,623 \geq 3,938)$ dan Sig hit $\leq \operatorname{Sig}_{\text {prob }}(0,000$ $\leq 0,05)$. Sesuai hipotesis yang diajukan dapat diperoleh simpulan bahwa ada 
pengaruh kualitas produk terhadap kepuasan pelanggan di rumah makan "Lesehan 88" Madiun. Berarti $\mathrm{H}_{0}$ ditolak, $\mathrm{H}_{\mathrm{a}}$ diterima.

\section{Simpulan Uji t}

Dari hasil perhitungan atau pengujian yang dilakukan diperoleh persamaan regresi sebagai berikut. $\mathrm{Y}=11,907+0,773 \mathrm{X}$, simpulannya adalah apabila kualitas produk ditingkatkan sebanyak 1\% akan terjadi kenaikan kepuasan pelanggan sebanyak $0,773 \%$, apabila faktor lainnya tetap. Hasil dari uji t dapat diperoleh nilai $t_{\text {hitung }}$ sebesar 11,297 sedangkan $t_{\text {tabel }}$ sebesar 1,660. Dilain pihak nilai $\mathrm{Sig}_{\text {hit }}$ sebesar 0,000 sedangkan $\mathrm{Sig}_{\text {prob }}$ 0,05. Hal ini berarti nilai $\mathrm{t}_{\text {hitung }} \leq \mathrm{t}_{\text {tabel }}$ $(11,297 \geq 1,660)$ atau $\operatorname{Sig}_{h i t} \leq \operatorname{Sig}_{\text {prob }}(0,000 \leq 0,05)$. Sesuai hipotesis yang diajukan dapat diperoleh simpulan bahwa ada beda pengaruh kualitas produk terhadap kepuasan pelanggan di rumah makan "Lesehan 88" Madiun. Berarti $\mathrm{H}_{0}$ ditolak, $\mathrm{H}_{\mathrm{a}}$ diterima.

\section{Pembahasan Hasil Analisis}

Dalam metode regresi memuat unsur uji korelasi, uji Fisher, dan uji t. Pembahasan untuk masing-masing uji berdasarkan hasil pengujian hipotesis adalah sebagai berikut:

\section{Pembahasan Uji Korelasi}

Untuk uji korelasi diperoleh nilai $r_{\text {hitung }}$ sebesar 0,752 sedangkan $r_{\text {tabel }}$ dengan $\mathrm{n}=100$ dan probabilitas 0,05 sebesar 0,195. Dilain pihak nilai $\mathrm{Sig}_{\text {hit }}$ sebesar 0,000 dan Sig prob sebesar 0,05. Hal ini berarti nilai $r_{\text {hitung }} \geq r_{\text {tabel }}(0,752 \geq$ $0,195)$ atau $\operatorname{Sig}_{\text {hit }} \leq \operatorname{Sig}_{\text {prob }}(0,000 \leq 0,05)$. Dengan demikian $\mathrm{H}_{0}$ ditolak, artinya ada hubungan kualitas produk terhadap kepuasan pelanggan di rumah makan "Lesehan 88" Madiun.

Nilai $\mathrm{R}^{2}$ yang diperoleh adalah sebesar 0,566. Menunjukkan bahwa kualitas produk mempengaruhi kepuasan pelanggan sebanyak 56,6\%.

Dengan demikian Kualitas produk mempunyai hubungan yang sangat erat dengan kepuasan pelanggan karena kualitas produk dapat dinilai dari kemampuan produk tersebut untuk menciptakan kepuasan pelanggan. Untuk memuaskan pelanggan maka, pihak rumah makan di dalam pengolahan produk harus berkualitas sehingga konsumen akan merasa puas. Kualitas produk ini dapat dilihat dari kebersihan produk, cita rasa makanan yang sesuai harapan, menu produk, dan porsi makanan.

Sesuai dengan pernyataan Kotler, (2008: 144) yang mengatakan semakin tinggi tingkat kualitas, semakin tinggi tingkat kepuasan pelanggan yang dihasilkan, yang mendukung harga yang lebih tinggi dan (sering kali) biaya yang lebih rendah.

\section{Pembahasan Uji Fisher}

Untuk uji Fisher diperoleh nilai $F_{\text {hitung }}$ sebesar 127,623 sedangkan nilai $\mathrm{F}_{\text {tabel }}$ dengan $\mathrm{n}=100$ dan probabilitas 0,05 sebesar 3,938. Dilain pihak nilai Sig hit $_{\text {hit }}$ sebesar 0,000 dan $\operatorname{Sig}_{\text {prob }}$ sebesar 0,05. Hal ini berarti bahwa nilai $F_{\text {hitung }} \geq F_{\text {tabel }}$ $(127,623 \geq 3,938)$ dan $\operatorname{Sig}$ hit $\leq \operatorname{Sig}_{\text {prob }}(0,000 \leq 0,05)$. Dengan demikian $\mathrm{H}_{0}$ 
ditolak, artinya ada pengaruh kualitas produk terhadap kepuasan pelanggan di rumah makan "Lesehan 88" Madiun.

Sesuai dengan pendapat Rambat Lupiyoadi (2001: 158) mengatakan bahwa kepuasan pelanggan dipengaruhi oleh lima faktor diantaranya, kualitas produk, kualitas pelayanan, emosional, harga, dan biaya. Penilaian pelanggan terhadap kualitas produk sangat subyektif, khususnya di rumah makan, oleh karena itu harus memperhatikan kualitas produk yang dihasilkan. Pelanggan akan merasa puas apabila hasil evaluasi mereka menunjukkan produk yang dihasilkan berkualitas.

\section{Pembahasan Uji t}

Dapat dilihat pada hasil persamaan $\mathrm{Y}=11,907+0,773 \mathrm{X}$. artinya apabila kualitas produk meningkat sebanyak $1 \%$ kepuasan pelanggan akan meningkat pula sebesar $0,773 \%$, apabila faktor lainnya tetap. Untuk uji t diperoleh nilai $t_{\text {hitung }}$ sebesar 11,297 sedangkan $t_{\text {tabel }}$ sebesar 1,660. Dilain pihak nilai Sig $_{\text {hit }}$ sebesar 0,000 sedangkan $\operatorname{Sig}_{\text {prob }}$ 0,05. Hal ini berarti nilai $t_{\text {hitung }} \leq t_{\text {tabel }}(11,297 \geq 1,660)$ atau $\operatorname{Sig}_{\text {hit }} \leq \operatorname{Sig}_{\text {prob }}(0,000 \leq 0,05)$. Dengan demikian $\mathrm{H}_{\mathrm{a}}$ diterima, artinya ada beda pengaruh antara kualitas produk terhadap kepuasan pelanggan di rumah makan "Lesehan 88" Madiun. Dari hasil penelitian menunjukkan bahwa kualitas produk mempunyai hubungan sekaligus pengaruh terhadap kepuasan pelanggan. Artinya jika kualitas produk meningkat, kepuasan pelanggan juga akan meningkat.

Kualitas produk merupakan salah satu tolok ukur yang digunakan dalam upaya peningkatan kepuasan pelanggan. Dengan penyediaan kualitas produk yang baik, akan mendorong pelanggan untuk datang dan pada akhirnya merasa terpuaskan dengan kualitas produk yang terjamin.

Pelanggan adalah orang yang menerima hasil pekerjaan (produk) pelaku bisnis, maka pelangganlah yang menentukan kualitas suatu produk. Kualitas produk dalam usaha rumah makan dapat dilihat dari kebersihan produk, cita rasa makanan, menu yang disajikan, dan porsi yang pas.

Sesuai dengan pendapat M.N Nasution (2001: 46) yang mengatakan jika kualitas produk yang dirasakan oleh pelanggan melebihi keinginan, harapan, dan kebutuhannya, maka kepuasan pelanggan akan menjadi tinggi. Disisi lain apabila pelanggan merasakan kualitas produk lebih rendah atau lebih kecil dari harapan, keinginan, dan kebutuhannya maka kepuasan pelanggan akan menjadi lebih rendah atau lebih kecil,).

Dengan demikian apabila kualitas produk dalam suatu usaha, khususnya rumah makan tersebut baik sehingga mendorong pelanggan berkunjung dengan perasaan nyaman dan akhirnya pelanggan akan terpuaskan. Oleh karena itu dikatakan bahwa kualitas produk memiliki pengaruh terhadap kepuasan pelanggan di suatu usaha rumah makan.

\section{PENUTUP}

\section{Kesimpulan}


Kualitas produk di rumah makan "Lesehan 88" Madiun adalah baik. Dapat dilihat dari hasil analisis 100 pelanggan bahwa hasil kuesioner yang banyaknya di atas nilai rata-rata 74 orang atau $74 \%$.

Kepuasan pelanggan yang ada di rumah makan "Lesehan 88" Madiun adalah baik. Dapat dilihat dari hasil analisis 100 pelanggan bahwa hasil kuesioner yang banyaknya di atas nilai rata-rata sebanyak 72 orang atau $72 \%$.

Ada pengaruh antara kualitas produk terhadap kepuasan pelanggan. Karena dengan adanya kualitas produk yang baik dapat meningkatkan kepuasan pelanggan, sehingga pelanggan akan datang kembali dan menjadi pelanggan rutin (heavy user). Hal tersebut didukung dengan hasil penelitian dengan nilai korelasi $r_{\text {hitung }}$ sebesar 0,752 sedangkan $r_{\text {tabel }}$ sebesar 0,195 $(0,752 \geq 0,195)$. atau nilai Sig hit sebesar 0,000 sedangkan Sig prob sebesar 0,05 $(0,000 \leq 0,05)$, untuk uji Fisher diperoleh nilai $F_{\text {hitung }}$ sebesar 127,623 sedangkan $F_{\text {tabel }}$ sebesar 3,938 (127,623 $\geq$ 3,938) atau nilai Sig $_{\text {hit }}$ sebesar 0,000 sedangkan $\operatorname{Sig}_{\text {prob }}$ sebesar $0,05(0,000 \leq$ $0,05)$, dan uji $t$, nilai $t_{\text {hitung }}$ sebesar 11,297 sedangkan $t_{\text {tabel }}$ sebesar 1,660 (11,297 $\geq$ $1,660)$ atau nilai $\operatorname{Sig}_{\text {hit }}$ sebesar $0,000 \leq \operatorname{Sig}_{\text {prob }}$ sebesar $0,05(0,000 \leq 0,05)$. Dilain pihak diperoleh nilai $\mathrm{R}^{2}$ sebesar 0,566 , artinya sumbangan pengaruh dari kualitas produk terhadap kepuasan pelanggan yaitu 56,6\% sedangkan sisanya 43,4\% dipengaruhi oleh faktor lain yang tidak diteliti. Dari semua uji di atas dapat diambil simpulan bahwa $\mathrm{H}_{\mathrm{a}}$ diterima, artinya di rumah makan "Lesehan 88" Madiun kualitas produk mempunyai pengaruh terhadap kepuasan pelanggan.

\section{Saran}

Sesuai dengan kesimpulan dari penelitian penulis lakukan di rumah makan "Lesehan 88" Madiun maka penulis memberikan saran yang nantinya dapat bermanfaat untuk meningkatkan kepuasan pelanggan yang ada di rumah makn "Lesehan 88" Madiun, adapun saran-saran tersebut antara lain sebagai berikut:

\section{Bagi Rumah Makan "Lesehan 88"}

Kualitas produk terbukti besar pengaruhnya terhadap kepuasan pelanggan, oleh karena itu yang harus dilakukan pihak rumah makan "Lesehan 88" Madiun diantaranya:

1. Pihak rumah makan "Lesehan 88" Madiun perlu mempertahankan dan meningkatkan kualitas produk dengan memberikan produk yang dapat memuaskan pelanggan.

2. Pihak rumah makan "Lesehan 88 " Madiun hendaknya selalu mengadakan perbaikan kualitas produk terutama kebersihan produk, menu produk dan cita rasa produk.

3. Pihak rumah makan "Lesehan 88 " Madiun diharapkan melakukan promosi untuk semakin mengenalkan produk kepada pelanggan dengan maksud agar pelanggan lebih mengenal produk dan akhirnya membeli produk kemudian menjadi pelanggan rutin (heavy user).

\section{Bagi IKIP PGRI Madiun}

Guna memperlancar proses penelitian yang dilakukan oleh mahasiswa hendaknya pihak kampus lebih memperbanyak buku-buku bahan pustaka. 


\section{Bagi Penelitian mendatang}

Bagi penelitian yang akan datang sebaiknya mengadakan pengembangan penelitian ini dengan menggunakan variabel bebas selain kualitas produk. Karena selain kualitas produk masih banyak faktor yang mempengaruhi kepuasan pelanggan di rumah makan.

\section{DAFTAR PUSTAKA}

Achmad Zanbar Sholeh. 2005. Ilmu Statistika Pendekatan Teoritis dan aplikatif Disertai Contoh Penggunaan SPSS. Bandung: Rekayasa Sains

Algifari. 2003. Statistika Induktif. Yogyakarta: Akademi Perusahaan YKPN.

Burhan Bungin. 2005. Metodologi Penelitian kuantitatif. Jakarta: Prenada Media.

Duwi Priyatno. 2010. Teknik Mudah dan Cepat Melakukan Analisis Data Penelitian Dengan SPSS dan Tanya Jawab Ujian Pendadaran. Yogyakarta: Gava Media.

Dorothea Wahyu Ariani. 2003. Manajemen Kualitas Pendekatan Sisi Kualitatif. Jakarta: Ghalia Indonesia.

Fandy Tjiptono. 2005. Pemasaran jasa. Malang: Bayumedia Publishing.

Fandy Tjiptono dan Anastasia Diana. 2002. Total Quality management. Yogyakarta: Andi Offset.

Gabriel Amin Silalahi. 2003. Metodologi Penelitian dan Studi Kasus. Sidoarjo: Citra Media.

Husein Umar. 2011. Metodologi Penelitian Untuk Skripsi dan Tesis Bisnis. Jakarta: PT Raja Grafindo Persada.

Iqbal Hasan. 2004. Analisis Data Penelitian Dengan Statistik. Jakarta: PT Bumi Aksara.

Juliansyah Noor. 2011. Metodologi Penelitian Skripsi, Tesis, Disertasi, dan Karya Ilmiah. Jakarta: Kencana Prenada Media Group.

Kotler, Philip dan Keller, Kevin Lane. 2008. Manajemen Pemasaran. Jakarta: Erlangga.

M.N Nasution. 2001. Manajemen Mutu terpadu (Total Quality Management). Jakarta: Ghalia Indonesia. 
Moehar Daniel 2003. Metodologi Penelitian Sosial dan Ekonomi. Jakarta: PT Bumi aksara.

Nanang Martono. 2010. Metode Penelitian Kuantitatif Analisis Isi dan Analisis Data Sekunder. Jakarta: PT RajaGrafindo Persada.

Nana Syaodih Sukmadinata. 2007. Metode Penelitian Pendidikan. Bandung: PT Remaja Rosdakarya.

Pandji Anoraga. 2007. Pengantar Bisnis Pengelolaan Bisnis Dalam Era Globalisasi. Jakarta: Rineka Cipta.

Pramudya Sunu. 1999. Peran SDM Dalam penerapan ISO 9000. Jakarta: PT Grasindo.

Rambat Lupiyoadi. 2001. Manajemen Pemasaran Jasa Teori dan Praktik. Jakarta: Salemba Empat.

Sugiyono. 2006. Metodologi Penelitian Kuantitatif, Kualitatif dan $R \& D$. Bandung: Alfabeta.

Suharsimi Arikunto. 2010. Prosedur Penelitian Suatu Pendekatan Praktik. Jakarta: Rineka Cipta.

Sukardi. 2003. Metodologi Penelitian Pendidikan Kompetensi dan Praktiknya. Jakarta: PT Bumi Aksara.

Thamrin Abdullah dan Francis Tantri. 2012. Manajemen Pemasaran. Jakarta: PT RajaGrafindo Persada.

TIM IKIP PGRI MADIUN. 2013. Pedoman Penulisan skripsi. Madiun: Institut Press

Usman Rianse dan Abdi. 2012. Metodologi Penelitian Sosial dan Ekonomi Teori dan aplikasi. Bandung: Alfabeta.

Zulian Yamit. 2005. Manajemen Kualitas. Yogyakarta: Ekonesia. 